
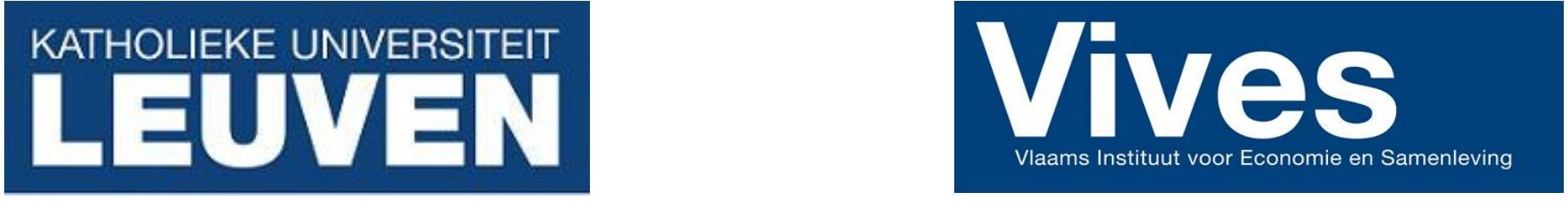

Naamsestraat 61 - bus 3550

B-3000 Leuven - BELGIUM

Tel : 32-16-326661

vives@econ.kuleuven.be

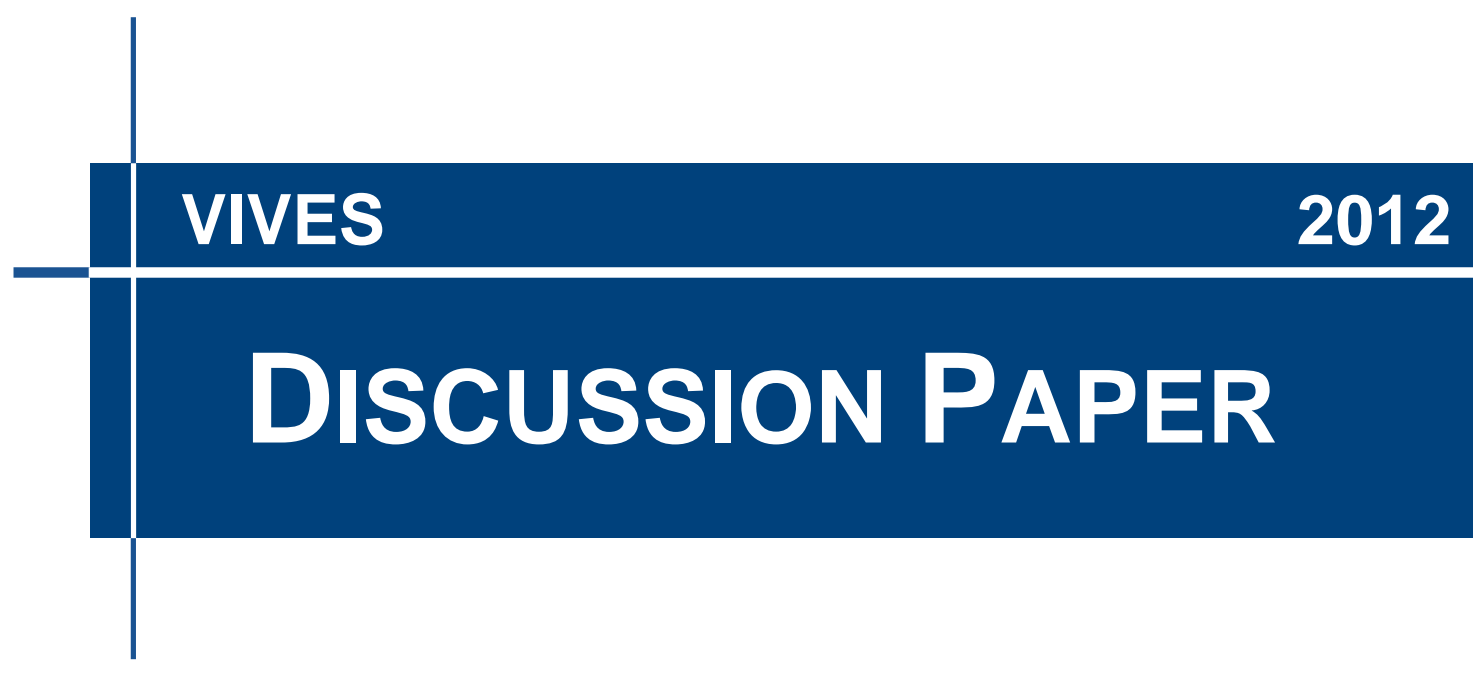

30

\title{
Start-up absorptive capacity: Does the owner's human and social capital matter?
}

\author{
Jonas Debrulle \\ jonas.debrulle@econ.kuleuven.be \\ [tel] +32 16324230
}

Copyright $@ 2012$ by K.U.LEUVEN, VIVES. Discussion papers are in draft form. This discussion paper is distributed for purposes of comment and discussion only. It may not be reproduced without permission of the copyright holder. 


\title{
START-UP ABSORPTIVE CAPACITY: DOES THE OWNER'S HUMAN AND SOCIAL CAPITAL MATTER?
}

\begin{abstract}
This study investigates how business owner human and social capital affect start-up absorptive capacity under different environmental conditions. From our analysis of a sample of 199 Flemish start-ups, we observe that the owner's start-up experience and bridging social capital are positively and significantly related to the new venture's ability to acquire, assimilate and exploit external information. In addition, our findings reveal a positive but decreasing effect of owner specific human capital as a function of environmental turbulence. Furthermore, we find that management experience significantly stimulates start-up absorptive capacity within highly dynamic environments, whereas it hinders it within stable environments. Finally, implications and opportunities for future research are provided.
\end{abstract}

Keywords: Start-up, organizational absorptive capacity, business owner, human capital, social capital, environmental turbulence. 


\section{START-UP ABSORPTIVE CAPACITY: DOES THE OWNER'S HUMAN AND SOCIAL CAPITAL MATTER?}

\section{INTRODUCTION}

With the emergence of the knowledge-based economy, organizations of many kinds increasingly rely on knowledge and scarce information to enhance their performance (Ireland et al., 2002; Zahra et al., 2000). Prior work has provided proof of the strategic importance of adequate information processing and of the centrality of knowledge to the firm (Sapienza et al., 2005). As such, a firm's absorptive capacity, being its ability to identify, assimilate and exploit new external information, could represent a major source of competitive advantage (Zahra and George, 2002).

Processing information efficiently is important for all firms, but absorptive capacity is of special importance for start-ups. Because start-ups are less fettered by bureaucracy and can arguably adapt quickly to a changing environment, their efforts devoted to the acquisition, assimilation and exploitation of external information could represent a means to get ahead of established competitors (Liao et al., 2003). As an important precondition to yield a competitive advantage from new knowledge is set in the speed by which identified information is processed (Zahra and George, 2002), a pronounced absorptive capacity is expected to strengthen the start-up's delicate competitive position, while simultaneously adding to the venture's survival (Keh et al., 2007; Sapienza et al., 2006; West and Noel, 2009). Start-ups often possess a narrow organizational and technological repertoire, resulting in a lopsided knowledge base, few capabilities and a limited capacity to cultivate other capabilities (Zahra and Filatotchev, 2004). This is not to say that internal knowledge sources have no value for start-ups. Yet, to cope with the challenges they face, and based on the typical cards they are dealt, they have a relatively higher need for new knowledge. Their absorptive capacity can generate this knowledge from external information. Not only does startup absorptive capacity allow the firm to better appreciate and understand the significance of external signals, it also aids in overcoming various competence and failure traps (Ahuja and Lampert, 2001; Levinthal and March, 1993). Because of their relatively limited financial resources, narrow technological inventory and restricted risk-bearing capability, start-ups are more prone to get caught in these traps than their established competitors (Liao et al., 2003). As absorptive capacity can introduce firms to atypical information that 
challenges the organization's cognitive understanding, it might reduce the risk of incessantly refining the existing knowledge base (familiarity trap), of unilaterally aspiring to predictable outcomes (maturity trap) and of precluding the exploration of novel knowledge areas (propinquity trap).

Despite the fact that individual cognition is recognized as a powerful internal driver of absorptive capacity (Cohen and Levinthal, 1990; Lane et al., 2006), little empirical evidence exists on the significance of the individual's knowledge base as an organizational absorptive capacity mainstay. Empirically disregarding the individual in absorptive capacity research causes the relegation of the construct to a mere mathematical heuristic whereby a certain amount of external information (input) produces an expected increase in the organization's knowledge base (output) (Lane et al., 2006). In particular, start-ups are especially dependent on the knowledge resources provided by the entrepreneur or business owner (Brush et al., 2001; Thorpe et al., 2005). Therefore, in order to address the above research deficit, this study aims to find empirical evidence of a business owner's direct contribution to the start-up's ability to acquire, assimilate and exploit new information. In doing so, we adopt a human and social capital lens. Note that though we recognize the central role of the business owner as the strategic decision maker of the firm, who affects organizational absorptive capacity indirectly through the articulation of strategy, the allocation of resources, the definition of tasks and the empowerment of employees, our research emphasis is on his/her direct contribution. By narrowing the scope in this way, we aim to reemphasize and empirically confirm Cohen and Levinthal's (1990) assumption of individual knowledge as the construct's mainstay.

Because information processing is rooted within an environmental context (Jansen et al., 2006; Lichtenthaler, 2009), firms operating in a turbulent environment, characterized by abundant and constantly evolving knowledge, have been found to engage in more external knowledge processing in order to develop or maintain their organization-environment fit (Becherer and Maurer, 1997; Liao et al., 2003; Miller and Friesen, 1983; Nicholls-Nixon et al., 2000). Although previous work proposes a significant role for environmental turbulence in shaping the firm's ability to harvest external information, we know very little of its importance regarding the relationship between individual cognition and organizational absorptive capacity. Therefore, we introduce environmental turbulence into our modeling framework and examine its impact on the owner's direct absorptive capacity contribution. 
This study contributes to the absorptive capacity and entrepreneurship literature in several ways. First, we shed light on the mechanisms by which individual human and social capital can add to a start-up's ability to effectively accumulate and absorb external information. As such, this study provides empirical evidence on one of the construct's fundamental premises: that the organization's absorptive capacity builds on the accumulated knowledge base of its constituents (Cohen and Levinthal, 1990). We thus respond to the criticism of Lane et al. (2006) that earlier empirical research has largely ignored the firm's individual members as responsible for uniquely creating organizational value from new knowledge. Second, while reemphasizing individual mental models and the personal knowledge base as essential internal drivers of the firm's external information processing, we abandon the traditional (rather one-sided) assumption that 'more accumulated capital is better'. Instead, we posit and empirically test positive and negative relationships between the owner's (human and social) capital and start-up absorptive capacity. We also consider the effect of human and social capital to be a function of the environment in which the start-up operates. Third, and building on the preceding points, we expose the owner's human and social capital as potential absorptive capacity antecedents, thereby empirically confirming that powerful actors within the firm possess the ability to influence knowledge processes (Todorova and Durisin, 2007). Fourth, our emphasis on start-ups responds to the scant attention paid to new ventures within the absorptive capacity literature. Although it has been argued that new ventures are strongly dependent on knowledge-related capabilities for their growth, survival and innovativeness, they are rarely employed as a research population to study these capabilities.

This article proceeds as follows. First, we address the concept of organizational absorptive capacity and review previous research on human and social capital. We then capture the notion of environmental turbulence and discuss its anticipated impact on the model. We identify gaps in existing research and define several hypotheses to be tested. Next, we describe our research methodology with a special focus on sampling procedures, measures and model tests. Finally, we present and discuss our findings, and conclude with some caveats and opportunities for future research. 


\section{THEORETICAL BACKGROUND}

Absorptive capacity research regards firms as systems that encompass the processes of noticing, interpreting and using information from their environment (Cohen and Levinthal, 1990; Lane et al., 2006). In their seminal contribution, Cohen and Levinthal (1990) refer to absorptive capacity as one of the firm's core processes, which designates its ability to identify, assimilate and exploit external information. They also consider absorptive capacity to be cumulative by nature, whereby 'accumulating absorptive capacity in one period permits its more efficient accumulation in the next' (Cohen and Levinthal, 1990, p. 136). Zahra and George (2002) add to Cohen and Levinthal's (1990) pathdependent understanding of the construct that absorptive capacity constitutes a dynamic capability 'which defines the firm's path of evolution' (p. 188) and enables the venture to yield a competitive advantage. What is key to Cohen and Levinthal's (1990) assumptions and propositions about the absorptive capacity construct is that individuals, similar to organizations, are equally assumed to acquire information and put new knowledge into memory. Afterwards, they can recall and use this knowledge in order to generate new insights. Upon transferring this understanding of the individual level to the organizational level, Cohen and Levinthal (1990) posit that organizational knowledge processing de facto builds on the corresponding individual capabilities of each of the firm's constituents. Specifically, they argue that for external knowledge to evolve into an organizational competitive advantage, individuals are required to creatively and uniquely acquire, interpret, communicate and combine information.

Though we recognize that organizational absorptive capacity and its underlying processes capitalize on the personal knowledge base of each of the firm's constituents (Cohen and Levinthal, 1990), within the realm of start-ups, we perceive the owner as the 'primus inter pares'. Two arguments support this view. First, owners have a hand in practically every aspect of the new business, which causes the new venture's evolutionary path to be intertwined with the owner's vision, convictions and knowledge (West and Noel, 2009; Wiklund and Shepherd, 2003; Zhang et al., 2006). Second, start-up owners often act as gatekeepers or interface between the new firm and its environment and/or between subunits of the firm (Smeltzer et al., 1988). These gatekeepers scan the venture's environment for important information, bring new knowledge into the organization and communicate this knowledge across unit boundaries (Cohen and Levinthal, 1990). As a result, the owner is able to affect the ideas and knowledge that propagate throughout the start-up. 
Consistent with prior research, we focus on two knowledge bases of the owner: human capital and social capital. From a human capital perspective, individuals can accrue additional knowledge by investing in general and/or specific human capital (Becker, 1993; Bosma et al., 2004; Gimeno et al., 1997). General human capital refers to skills that are useful and transferable across a wide range of situations (e.g. occupational alternatives, economic settings), whereas specific human capital is more related to a specific setting and has a much narrower scope of applicability (Gimeno et al., 1997; Ucbasaran et al., 2008). In order to build human capital, individuals may participate in one of three kinds of education: formal education (e.g. high school or university education), informal education (e.g. work experience) or non-formal education (e.g. adult education) (Davidsson and Honig, 2003). In addition, human capital might be accumulated through experiential learning (e.g. management experience, industry experience) without any explicit investment decision being made (Ucbasaran et al., 2008).

As a core organizational member, the owner is perceived as an important reservoir of knowledge through his/her human capital (Smith et al., 2005). Within this study we develop separate hypotheses for the relationships between general and specific human capital on the one hand and start-up absorptive capacity on the other. The reason for this separate treatment can be found in the likely existence of differing mechanisms by which absorptive capacity and competitive advantage effects are triggered. Specifically, general human capital, which largely emerges from prior formal education and management experience (Bates, 1990; Gimeno et al., 1997), is considered a source of generic abilities, intelligence and skills. It generates a wider individual knowledge base and improves general cognitive reasoning, cognitive processing and problem solving skills (Bierly et al., 2009; Chandler and Lyon, 2009; Smith et al., 2005). Furthermore, it reflects a motivational need for achievement (Hatch and Dyer, 2004) and increases the commitment and effort devoted to further knowledge searching, acquisition and interpretation (Autio et al., 2000; De Clercq et al., 2005). People with greater levels of formal education are also expected to be more receptive to new ideas and change (Boeker, 1997). As such, given that education and management experience foster individual knowledge-creating capabilities, that organizational absorptive capacity capitalizes on the knowledge accumulated by its constituents and that the business owner assumes a central role within the start-up, we expect the owner's general human capital, as reflected in formal education and management experience, to add to the information processing ability of the start-up. As a result, we predict that: 
Hypothesis 1: The business owner's general human capital is positively associated with start-up absorptive capacity. This will be reflected in a positive effect of:

a) formal education, and

b) management experience.

Apart from the anticipated positive effect of general human capital, recent contributions increasingly recognize individual knowledge and knowledge processing as the outcomes of a situated understanding about what works when and where (Thorpe et al., 2005; West and Noel, 2009). According to these authors, knowledge needs to be related to the venture if it is to produce (organizational) benefits. Given their less transferable nature and focused relevance to specific occupations or contexts (Gimeno et al., 1997), we perceive the business owner's experience in the new venture's industry, as well as his/her previous start-up experience, as potential sources of such venture-related knowledge. That is to say, both industry and start-up experience entail knowledge of particular customers, suppliers, products and services, which creates value in a specific industry setting and relates to a limited scope of occupational alternatives (Gimeno et al., 1997). Moreover, both deliver procedural knowledge on how to perform particular tasks, on the pitfalls that may lie ahead, and on steps that should (not) be taken (West and Noel, 2009). In addition, these types of specific human capital (Gimeno et al., 1997; Ucbasaran et al., 2008) influence perception because they focus attention to issues related to already accumulated experience and stimulate further knowledge accumulation with regard to those issues (Fiet, 1996; Ocasio, 1997). Though this might imply that industry and start-up experience inhibit some forms of radical change, we contend that both increase the owner's knowledge with regard to markets and customers. What is more, given the aforementioned pivotal role of the owner within the start-up, we expect his/her accumulated specific human capital will equally instill the start-up on where to look for information and how to effectively acquire, assimilate and exploit it. In other words, we believe that owner specific human capital, as reflected in industry and start-up experience, not only stimulates the owner's personal information processing capability but also that of the new venture:

Hypothesis 2: The business owner's specific human capital is positively associated with start-up absorptive capacity. This will be reflected in a positive effect of:

a) industry experience, and

b) start-up experience. 
Apart from human capital, individuals also build knowledge by investing in social capital. Taken as a whole, social capital refers to the ability of actors, both individuals and organizations (Nahapiet and Ghoshal, 1998), to profit from their social structures, networks and community-based relationships (Davidsson and Honig, 2003; Lin et al., 1981; Portes, 1998). In a general sense, social capital is able to affect absorptive capacity in various ways. For instance, it provides privileged access to information and opportunities (Yli-Renko et al., 2001), which may have a goal-directing and motivating effect on further knowledge accumulation. Additionally, it influences cognition (De Carolis et al., 2009) and might institutionalize acquisition, assimilation and/or exploitation mechanisms for more effective and efficient future information processing (Bierly et al., 2009). Social capital can also decrease the probability of opportunism in the knowledge exchange process and, therefore, reduce its transaction costs (Nahapiet and Ghoshal, 1998). This increases the expected return and makes investing in external information all the more attractive. Finally, social capital affects the fundamental conditions that stimulate knowledge exchange. Specifically, the exchange of knowledge is commonly founded on trust (Hayton, 2005), which is also key to the development of social capital (Granovetter, 1983).

Previous work has indicated that within new ventures the organization's need for social capital is initially satisfied by borrowing from an individual's social capital (Arrègle et al., 2007). Furthermore, the significance of individual social capital for new ventures has been demonstrated by its effect on the availability, timing, relevance and quality of tangible and/or intangible business resources (Adler and Kwon, 2002; De Carolis et al., 2009; Thorpe et al., 2005). These findings, combined with Cohen and Levinthal's (1990) construct assumptions and our premise of the business owner playing a prominent role within the start-up, lead us to believe that the owner's social capital, as a cornerstone of the start-up's social capital, is likely to affect startup absorptive capacity.

Similar to Davidsson and Honig (2003), we distinguish between the owner's bridging and bonding social capital. Bridging social capital or loose network relationships with, for instance, other professionals (weak ties) predominantly functions as an interface for the exchange of otherwise unavailable information and scarce resources. Bonding social capital or associations with family and close friends (strong ties) is rooted in interpersonal trust and can equip the owner with permanent access to a limited amount of specific resources (e.g. advice, aid) (Davidsson and Honig, 2003; Granovetter, 1983). Previous research has argued that tie strength affects the benefits that can be 
distilled from the specific relationship. For instance, Zahra and George (2002) mainly advocate the importance of strong ties or bonding social capital, whereas Todorova and Durisin (2007) also accentuate the significance of weak ties or bridging social capital, especially with respect to accessing novel information. According to Hansen (1999), social capital effectiveness regarding information processing depends on the knowledge activity at hand and on the type of knowledge being processed. Specifically, he finds that the use of bonding social capital is advised whenever knowledge is complex or subject to transfer. Vice versa, when confronted with simple knowledge or a search activity, bridging social capital appears to be more beneficial. In view of this social capital distinction, we develop separate hypotheses that link bonding (weak ties) and bridging (strong ties) social capital to start-up absorptive capacity.

Closeness, long duration, frequent interaction and more evident or generalized trust are characteristics of bonding social capital or strong ties (Smith et al., 2005). Thus, a suitable premise would be to assume that bonding social capital improves information exchange and cooperation, which increases the business owner's knowledge base and, in doing so, fosters organizational absorptive capacity. However, it has also been suggested that strong ties might not be that effective or useful when acquiring and exploiting ambiguous information, such as market and customer information (Nahapiet and Ghoshal, 1998). Consequently, as we will argue below, the owner's bonding social capital could have a negative influence on start-up absorptive capacity. More specifically, because of the aforementioned characteristics, a group or network within which strong ties are present generally displays a distinct identity with strong norms and shared meanings. Prior work has revealed that such an identity might produce a very selective focus on information, thereby constituting a significant barrier to new knowledge acquisition and creation (De Carolis et al., 2009; Nahapiet and Ghoshal, 1998; Simon and Davies, 1996). The level of generalized trust associated with bonding social capital has been argued not to be very conducive to the development of (additional) knowledge sources necessary for information acquisition (Kang et al., 2007). Besides, as bonding social capital generates a more collective understanding among all parties involved, comparable lower effort will be devoted to process any newly acquired information within such a network (Bierly et al., 2009). This suggests that bonding social capital might also negatively affect the absorptive capacity dimension of processing and utilizing new knowledge that has already been acquired and transferred within the firm. In view of these arguments, we propose: 
Hypothesis 3: The business owner's bonding social capital is negatively associated with start-up absorptive capacity.

In contrast to strong ties, weak ties (or bridging social capital) require a lower investment of time and resources (Smith et al., 2005). Contacts are scarcer, involve more dyadic trust and build on experience in specific interactions between two parties (Kang et al., 2007). In view of this lower degree of trust and collective understanding, an acceptable premise would be that the owner's bridging social capital slows down any valuable information exchange and cooperation, which in turn hinders the expansion of his/her personal knowledge base. As a consequence, the owner's bridging social capital, as a keystone of the start-up's bridging social capital, would equally impede organizational absorptive capacity. Yet, once again, we anticipate the opposite effect. We expect that as the dyadic type of trust governing bridging social capital restricts the exchange of in-depth knowledge (Leana and Van Buren, 1999), the firm will be pushed to acquire, assimilate and interpret additional external information in order to obtain the full knowledge base needed or wanted. Weak ties bring some efficiency benefits in terms of capturing information because they require less effort to build and maintain, and have lower coordination costs (Kang et al., 2007; Smith et al., 2005). Therefore, we believe that the owner's weak ties represent an effective and efficient means of obtaining such ad hoc information and knowledge. Bridging social capital also generates more diverse information (Nahapiet and Ghoshal, 1998). However, being immersed in a network that draws on diverse mental models of the world around them may trigger firms to become less confident about their undertakings (De Carolis et al., 2009). Once again, a successful way to cope with this is to acquire, assimilate and interpret even more knowledge and information. Hence:

Hypothesis 4: The business owner's bridging social capital is positively associated with start-up absorptive capacity.

Previous research has already emphasized that contextual factors might affect the relationship between organizational absorptive capacity and its drivers. For instance, Smith et al. (2005) suggested that strong ties are critical compared with weak ties when the knowledge context is ambiguous and uncertain. As such, within the remainder of this section, we specify the moderating impact of environmental turbulence on the linkages between the owner's human and social capital and start-up absorptive capacity. 
Absorptive capacity logic requires the presence of external information for the firm to create value (Cohen and Levinthal, 1990; Zahra and George, 2002). Such information often results from a change taking place in the firm's environment (Yli-Renko et al., 2001). So, the more turbulent the environment, the stronger the presence of various kinds of external information, and the more the conditions for organizational absorptive capacity to generate a competitive advantage are satisfied. In other words, environmental change challenges the organizational status-quo and stimulates the search for new information as a coping mechanism to deal with the uncertainty these changes may bring (Chandler and Lyon, 2009; Liao et al., 2003; Zhang et al., 2006). Although many start-ups may not be operating within turbulent environments an sich, their respective surroundings are, by definition, expected to display varying degrees of turbulence (Chandler and Lyon, 2009). This, together with the finding that different environments imply different valuations of dynamic capabilities (Eisenhardt and Martin, 2000), leads us to believe that the contribution of particular forms of an owner's human and social capital to absorptive capacity may be strengthened when environmental turbulence increases, whereas that of other forms could be weakened.

When environments become more turbulent, firms are faced with more and more diverse, ambiguous and uncertain information (Lichtenthaler, 2009). In turn, this ambiguity and uncertainty makes the absorptive capacity success determinants of recognizing and assimilating external knowledge considerably more challenging (Zahra and George, 2002). In this case, decision makers require a broad mindset containing a diverse set of issues and answers together with a lower degree of automatic attentional processing (Ocasio, 1997). In other words, under turbulent conditions, start-up business owners should benefit from human and social capital that offers them more cognitive flexibility and sensitivity. Specifically, those types of human and social capital that provide business owners with a less strong or selective view of the world around them may prove to be more useful in a turbulent setting, whereas the efficacy of more selective or environment-tailored capital will be progressively impeded. With respect to our research, we believe general human capital and bridging social capital to be examples of less selective capital. They represent more general, transferable cognitions and more loosely shared meanings. On the contrary, we assume specific human capital and bonding social capital to be more dependent on a specific environmental setting when it comes to successfully identifying, acquiring and assimilating knowledge. As such, in analogy with the aforementioned hypotheses, we propose that: 
Hypothesis 5: Environmental turbulence acts as a positive moderator of the relationship between the business owner's more transferable and flexible capital and start-up absorptive capacity. This will be reflected in a positive moderation of the effect of:

a) general human capital, and

b) bridging social capital.

Hypothesis 6: Environmental turbulence acts as a negative moderator of the relationship between the business owner's less transferable and flexible capital and start-up absorptive capacity. This will be reflected in a negative moderation of the effect of:

a) specific human capital, and

b) bonding social capital.

At this point we would like to emphasize that the above hypotheses only relate to the owner's direct contribution to start-up absorptive capacity. Note that we do not take any position on the owner's overall impact on absorptive capacity and its relationship with environmental turbidity. In fact, we would not be surprised if the owner's overall impact increases with the number of environmental changes. That is to say, the owner's pivotal role within the start-up may enable him/her to enhance absorptive capacity under turbulent conditions through the reallocation of resources, the adaptation of organizational tasks and the delegation of responsibility and power. Ultimately, this indirect impact could outweigh the above hypothesized loss of direct influence on absorptive capacity, but this is outside the scope of our research interest.

\section{METHODOLOGY}

\section{Sampling procedures}

This study builds on an extensive cross-sectional survey on start-ups located in Flanders, Belgium, called START 2009. This is a biennial population survey of Flemish incorporated companies aged between one and three years, active within various economic sectors, with a minimum of one and a maximum of forty-nine employees in 2009. Representing the fourth and latest edition of the cross-sectional START research program, START 2009 combines a company questionnaire with semi-structured interviews of each of the start-up's current business owners. 
The total research population of Flemish start-ups as defined above consisted of 3183 firms in 2009. Due to obsolete company data, 259 of these start-ups could not be reached. Out of the 2924 remaining start-ups, 453 company questionnaires and 490 owner interviews were obtained. Because data on both the start-up company and its owners is required for this study, we had to remove 68 companies (due to lack of data on the owners) and 13 owners (due to lack of data on the start-up) from this response group. In order to clearly demarcate a business owner's direct contribution to start-up absorptive capacity, we further limited our sample to starting ventures in which only one owner took responsibility for daily management (Dimov, 2010). Additionally, we only considered those start-ups in which the owner was the initial firm founder (Dimov, 2010). In doing so, we made sure that it was the current owner who spotted the opportunity, rallied sufficient financial support, requested counsel and assistance from friends and colleagues and translated his/her business idea into an actual business. As a result of these restrictions, the sample of this study was reduced to 262 companies which, because of the use of listwise exclusion during statistical procedures, resulted in a final sample of 199 start-ups. More than one-third of these start-ups (39.2\%) were active in the construction business, while one-fourth represented start-ups in the manufacturing sector $(25.1 \%)$. The remainder comprised professional services companies (14.6\%), banking and insurances companies (8\%), transportation businesses (7\%) and agricultural businesses (6\%). Tests between respondent and non-respondent firms revealed no significant difference in the age of the organization or its size (number of employees, total assets and equity). Moreover, using chi-square difference and t-tests, no difference could be detected regarding industry, size and age between the firms used in the analyses and those that were eligible but were excluded because of missing values on one or more of the variables.

\section{$\underline{\text { Measures }}$}

Absorptive capacity. Estimating absorptive capacity has been subject to much controversy. In the past, researchers have operationalized absorptive capacity by means of R\&D investments, patents, organizational age and size (Mowery et al., 1996; Muscio, 2007; Tsai, 2001). Not only do these proxies induce the reification of the absorptive capacity construct (Lane et al., 2006), they also fail to capture its underlying complex nature (Liao et al., 2003). That is why in this study we measure absorptive capacity using a construct representing (1) the acquisition of external information, (2) the assimilation of acquired information throughout the business and (3) its successful exploitation and application in commercial actions (Lane et al., 2006; Liao et al., 2003). Similar 
to Jansen et al. (2005), Liao et al. (2003) and Maes and Sels (forthcoming), we choose a market oriented approach to measure absorptive capacity. Start-ups are compelled to be market oriented if they want to head off their established competitors in the consumption of external information (Liao et al., 2003). After all, their limited resources impede the execution of customer preference analyses or wide-scale market scanning. As a result, start-ups frequently have to rely on market intelligence stemming from direct contacts with their customers and/or organizational network to obtain external information (Keh et al., 2007). In addition to shedding light on current customer demands, such market intelligence also adds to the company's understanding of (future) customer needs (Maes and Sels, forthcoming; Verhees and Meulenberg, 2004). The scale items used to measure market oriented absorptive capacity are adopted from Kohli et al. (1993) and Maes and Sels (forthcoming). Respondents were asked to rate a five-point Likert scale on five statements regarding market and customer external information processing (Cronbach's alpha $=.841$ ). In view of employing market intelligence as a measure for absorptive capacity, all items were set up to capture the intensity with which market information is absorbed (e.g. 'We periodically review our product development efforts to ensure that they are in line with what customers want') (Maes and Sels, forthcoming). The scale ranges from 0 to 100 using the factor formula suggested by Maes et al. (2005). This formula is outlined in Appendix A with all items and factor loadings.

Human capital. In accordance with prior research (Bates, 1990; Gimeno et al., 1997), we used the highest level of formal education and the number of years of management experience as measures of the business owner's general human capital. Possible answers on the education scale ranged from no education (1) to university degree (9). We consider management experience a proxy of work experience, which is commonly measured as the number of years of employment. However, as Bates (1990) suggested, management experience can be perceived as a level of achievement reached in employment, thereby giving it added value compared with using years of employment as an experience measure. To examine specific human capital, we interviewed the business owners about their number of years of industry experience and the number of times they had already actively participated in the process of starting up a business (Davidsson and Honig, 2003).

Bonding social capital. We operationalized the owner's social capital by identifying the individual's network structure and by assessing the quality of the connections constituting this network (Arrègle et al., 2007; Nahapiet and Ghoshal, 1998). Considering bonding social capital, we presented the owner 
with a list of several possible strong ties (e.g. parents, siblings, partners and friends). For each of these relationships, which are rooted in reciprocity and trust (Davidsson and Honig, 2003), we asked the owner to indicate whether he/she had ever received venture-related (non-financial) aid or assistance from it. If the response was affirmative, we then asked for the kind(s) of aid or assistance this strong tie (had) provided. Possible answers varied from general advice over administrative, technical and executive aid, to guidance in financial matters and bookkeeping (five categories). Based on this information, we established a bonding social capital index for each business owner by adding together the number of strong ties and the kind(s) of assistance each of these strong ties (had) provided.

Bridging social capital. Similar to bonding social capital, we presented each owner with a list of possible weak ties (e.g. professional contacts, employer organizations and loose relationships with industrial unions) and invited the respondent to indicate whether a specific weak tie had ever functioned as an interface of venture-related valuable information and what the quality of that information was ( 1 = very low quality; 5 = extremely high quality). In addition, we registered all professional associations in which the owner actively participated (e.g. service clubs and professional societies). On a fivepoint Likert scale ranging from (1) not influential to (5) extremely influential, we asked the owner to indicate the significance of each of these associations in terms of the start-up's development and sustainability. We then developed a bridging social capital index by adding together the number of weak ties and their indicated quality or importance.

(Perceived) Environmental turbulence. We determined the turbulent nature of the environment using an environmental dynamism factor based on Zahra (1993). Respondents were asked to rate a five-point Likert scale on seven environmental statements (e.g. 'Within our industry the need for a new technology is growing'). Possible answers varied from entirely disagree (1) to entirely agree (5). Using the formula suggested by Maes et al. (2005), we created a factor with scale ranges from 0 to 100 (Cronbach's alpha $=.894$ ). Once again, the adopted formula as well as the items and factor loadings are enlisted in Appendix A.

Control variables. To isolate our hypotheses from possible rival explanations and to minimize extraneous variation, we included owner age and gender, firm size, age of the business activities and start-up continuation as control variables. Liao et al. (2003) argue that size is a major influence in affecting firm behavior. We measured organizational size in terms of the number of 
full-time equivalents working in the firm. Although all start-ups in our sample are between one and three years of (legal) age, not all of them are novo start-ups. This implies that business activities could have been carried out before the current organization was established. Therefore, we control for the actual age of the business activities and for start-up continuation. The latter is done using a dummy variable ('start-up continuation') indicating whether or not the business activities were already operational before the current organization was legally established. Finally, because the start-ups in our sample belong to various industries, we developed a series of dummy variables to control for the different market conditions within each industry. Five dummies were included in our analyses, using the manufacturing sector as a reference category.

\section{Measurement validity tests}

To exclude concerns of common-method variance and to examine the construct, convergent and discriminant validity of the social capital, environmental turbulence and absorptive capacity measures, we took the following steps. Our research design minimizes possible common-method variance effects because we used two distinct methods to collect the necessary data (company questionnaire and semi-structured owner interview). Moreover, within both the questionnaire and the interview, open-ended questions were interspersed with other types of questions (e.g. Likert scale questions). This prevents respondents from adopting a scale-based pattern linked to Likert or semantic differential scales (Podsakoff et al., 2003).

We used Harman's single factor test to examine concerns of possible common-method variance between the two factors (environmental turbulence and absorptive capacity). This kind of variance might inflate or deflate the observed relationships, thereby leading to both Type I and Type II errors. The technique assumes that if a substantial amount of common-method variance is present, either a single factor will emerge from a factor analysis containing all predictor items or one general factor will account for the majority of the covariance among the measures (Podsakoff et al., 2003). From the unrotated factor structure, two factors with eigenvalues greater than one emerged. The first factor only explains $44 \%$ of the variance and at least eight factors are needed to explain $90 \%$ of it. Therefore, no general factor accounts for the majority of the covariance among the variables. The above result allows us to conclude that there is no concern for the presence of substantial commonmethod variance within our data. The same conclusion can be drawn from the confirmatory factor analysis reported next. 
Construct validity was established by developing measures from wellgrounded theory (Barringer and Bluedorn, 1999) (cf. measurement section). Confirmatory factor analysis was performed to assess the convergent and discriminant validity of the involved factors. We first analyzed an unconstrained model that included the environmental turbulence and absorptive capacity constructs in a way that each item loaded solely on the factor for which it was an intended indicator. The fit of this model is reasonably good $(\mathrm{GFI}=.90$; AGFI $=.84$; Comparative Fit Index $=.93$ ) (Browne and Cudeck, 1993; Hair et al., 1998). All items load significantly on their proposed factor (listed in Appendix A), which satisfies the convergent validity test (Anderson and Gerbing, 1988). Following Anderson and Gerbing (1988), we then examined discriminant validity by constraining the correlation between the two constructs to one. The difference between the chisquared value of the unconstrained model and that of the constrained model also has a chi-squared distribution with one additional degree of freedom. If this pair-wise difference exceeds 3.84 (the $5 \%$ critical value), then discriminant validity is said to be established. Because the chi-squared difference was well above 3.84 (53.47), the discriminant validity of both factors is demonstrated.

\section{$\underline{\text { Statistical procedures }}$}

Hierarchical regression analyses are used as the statistical procedure to test our hypotheses. The variables were mean-centered before creating the interaction terms with environmental turbulence. We used the SPSS statistical package. The highest VIF-statistic encountered is 2.567, which is well below the recommended maximum value of five (Kleinbaum et al., 1998; Moreno and Casillas, 2008). This demonstrates the likely absence of multicollinearity.

\section{RESULTS}

Table 1 presents the means, standard deviations and bivariate correlations of this study's variables. All correlations are well below .80 in absolute value, which is another indication against the possible presence of multicollinearity (Hair et al., 1998). The results of the hierarchical regression analyses are listed in Table 2. Model 1 of Table 2 represents the 'control model', which includes only the control variables. Models 2 to 4 relate to the human capital indicators together with the control variables, as does Model 5 for the social capital indicators. Model 6 includes the control variables as well as the indicators of both human and social capital (baseline model), while in Model 7 the moderator variable is added. The interaction terms are introduced in Models 8 and 9. Finally, Model 10 represents a full model. 
Table 1 Descriptive statistics and correlations

\begin{tabular}{|c|c|c|c|c|c|c|c|c|c|c|c|c|c|c|c|c|c|c|c|c|}
\hline Variables & Mean & S.D. & 1 & 2 & 3 & 4 & 5 & 6 & 7 & 8 & 9 & 10 & 11 & 12 & 13 & 14 & 15 & 16 & 17 & 18 \\
\hline $\begin{array}{l}\text { 1. Start-up absorptive } \\
\text { capacity }\end{array}$ & 36.47 & 24.02 & 1 & & & & & & & & & & & & & & & & & \\
\hline 2. Business owner gender & .91 & .27 & -.051 & 1 & & & & & & & & & & & & & & & & \\
\hline 3. Business owner age & 42.87 & 9.69 & .047 & $-.141^{*}$ & 1 & & & & & & & & & & & & & & & \\
\hline 4. Age of business activities & 11.83 & 16.19 & $-183^{* *}$ & .020 & $.197^{\star *}$ & 1 & & & & & & & & & & & & & & \\
\hline 5. Firm size & 5.67 & 13.18 & $.210^{* *}$ & .022 & .105 & -.007 & 1 & & & & & & & & & & & & & \\
\hline 6. Start-up continuation & .63 & .49 & $-.240^{* *}$ & $.155^{*}$ & .079 & $.562^{\text {** }}$ & -.002 & 1 & & & & & & & & & & & & \\
\hline 7. Agriculture & .06 & .24 & .011 & -.003 & -.020 & .083 & .070 & .108 & 1 & & & & & & & & & & & \\
\hline 8. Manufacturing & .25 & .44 & .078 & $-.212^{\star *}$ & .079 & .044 & -.020 & -.034 & $-.147^{\star}$ & 1 & & & & & & & & & & \\
\hline 9. Construction & .39 & .49 & $-.354^{* *}$ & .124 & -.130 & -.004 & -.127 & .128 & $-.203^{\text {** }}$ & $-.465^{* *}$ & 1 & & & & & & & & & \\
\hline 10. Transportation & .08 & .26 & .041 & .081 & $-.144^{*}$ & -.037 & .138 & -.114 & -.070 & $-.159^{*}$ & $-.221^{* *}$ & 1 & & & & & & & & \\
\hline 11. Banking and insurances & .08 & .27 & .021 & .019 & .069 & .082 & -.095 & .036 & -.075 & $-.171^{*}$ & $-.237^{* *}$ & -.081 & 1 & & & & & & & \\
\hline 12. Professional services & .14 & .35 & $.340^{* *}$ & .017 & $.149^{*}$ & $-.140^{*}$ & .126 & $-.154^{*}$ & -.105 & $-.239^{* *}$ & $-.332^{* *}$ & -.114 & -.122 & 1 & & & & & & \\
\hline 13. Formal education level & 4.78 & 1.95 & $.290^{* *}$ & .050 & $.176^{*}$ & .013 & .076 & -.110 & .020 & .041 & $-.432^{* *}$ & -.047 & .102 & $.490^{* *}$ & 1 & & & & & \\
\hline 14. Management experience & 11.95 & 8.96 & .029 & .002 & $.658^{* \star}$ & $.248^{* *}$ & .071 & $.184^{* *}$ & .075 & .060 & -.104 & -.134 & .056 & .075 & $.188^{* *}$ & 1 & & & & \\
\hline 15. Industry experience & 16.25 & 9.58 & -.016 & .078 & $.615^{* \star}$ & $.213^{\text {** }}$ & .049 & $.163^{*}$ & .046 & -.059 & .085 & $-.176^{*}$ & .119 & -.041 & .012 & $.550^{* *}$ & 1 & & & \\
\hline 16. Start-up experience & 2.10 & 2.28 & $.286^{* *}$ & .071 & $.276^{* *}$ & .021 & $.274^{* *}$ & -.082 & -.022 & .028 & $-.193^{* *}$ & -.057 & -.063 & $.337^{* *}$ & $.338^{* *}$ & $.371^{* *}$ & $.163^{*}$ & 1 & & \\
\hline 17. Bonding social capital & 2.62 & 2.46 & .050 & .037 & $-.267^{* *}$ & -.001 & .070 & -.122 & .090 & .065 & -.023 & .098 & $-.173^{*}$ & -.047 & -.041 & $-191^{* *}$ & $-.234^{* *}$ & .070 & 1 & \\
\hline 18. Bridging social capital & 14.51 & 7.75 & $.242^{2 *}$ & -.101 & -.088 & .005 & $.178^{*}$ & -.106 & -.028 & .039 & .003 & .058 & -.095 & -.002 & .040 & -.051 & -.063 & -.011 & $.201^{* *}$ & 1 \\
\hline $\begin{array}{l}\text { 19. Environmental } \\
\text { turbulence }\end{array}$ & 43.51 & 22.32 & $.404^{* *}$ & .102 & .002 & -.131 & .001 & -.111 & -.042 & .072 & -.025 & -.135 & -.084 & .138 & $.239^{* *}$ & .046 & -.019 & $.181^{\star}$ & .115 & .125 \\
\hline
\end{tabular}

**. Correlation is significant at the .01 level (two-tailed) - * Correlation is significant at the .05 level (two-tailed). 
Table 2 Results of hierarchical regression models of start-up absorptive capacity

\begin{tabular}{|c|c|c|c|c|c|c|c|c|c|c|}
\hline Variables & Model 1 & Model 2 & Model 3 & Model 4 & Model 5 & Model 6 & Model 7 & Model 8 & Model 9 & Model 10 \\
\hline \multicolumn{11}{|l|}{ Control variables } \\
\hline Business owner gender & -.003 & -.015 & -.035 & -.040 & .020 & -.014 & -.054 & -.056 & -.059 & -.060 \\
\hline Business owner age & -.014 & -.043 & -.098 & -.087 & .014 & -.051 & -.051 & -.082 & -.043 & -.073 \\
\hline Age of business activities & -.079 & -.089 & -.096 & -.100 & -.106 & -.122 & -.076 & -.066 & -.081 & -.071 \\
\hline Firm size & $.159^{*}$ & $.160^{*}$ & $.125^{\dagger}$ & $.125^{\dagger}$ & $.117^{\dagger}$ & .079 & .097 & .068 & .090 & .064 \\
\hline Start-up continuation & $-.132^{\dagger}$ & -.127 & -.115 & -.106 & -.100 & -.076 & -.070 & -.067 & -.078 & -.076 \\
\hline Agriculture & -.014 & -.016 & -.015 & -.014 & -.004 & -.001 & .021 & .018 & .022 & .019 \\
\hline Construction & $-.262^{* *}$ & $-.236^{* *}$ & $-.257^{* *}$ & $-.242^{* *}$ & $-.264^{* * *}$ & $-.249^{* *}$ & $-.244^{* *}$ & $-.251^{* *}$ & $-.240^{* *}$ & $-.250^{* *}$ \\
\hline Transportation & -.037 & -.029 & -.019 & -.016 & -.036 & -.017 & .040 & .053 & .038 & .052 \\
\hline Banking and insurances & .006 & .002 & .009 & .004 & .022 & .021 & .055 & .039 & .061 & .045 \\
\hline Professional services & $.199 *$ & $.170^{*}$ & $.173^{*}$ & $.150^{\dagger}$ & $.204^{* *}$ & $.158^{*}$ & $.179^{*}$ & $.190^{*}$ & $.193^{*}$ & $.198^{*}$ \\
\hline \multicolumn{11}{|l|}{ General human capital } \\
\hline Formal education level & & .079 & & .062 & & .040 & -.037 & -.056 & -.049 & -.065 \\
\hline Management experience & & .036 & & -.034 & & -.047 & -.058 & -.030 & -.055 & -.030 \\
\hline \multicolumn{11}{|l|}{ Specific human capital } \\
\hline Industry experience & & & .081 & .091 & & .082 & .087 & .095 & .100 & .106 \\
\hline Start-up experience & & & $.153^{*}$ & $.151^{*}$ & & $.170^{*}$ & $.135^{*}$ & $.179 *$ & $.127^{*}$ & $.170^{*}$ \\
\hline \multicolumn{11}{|l|}{ Social capital } \\
\hline Bonding social capital & & & & & -.001 & -.017 & -.049 & -.061 & -.040 & -.049 \\
\hline Bridging social capital & & & & & $.220^{* * *}$ & $.226^{* * *}$ & $.186^{* *}$ & $.201^{* * *}$ & $.197^{* *}$ & $.211^{* * *}$ \\
\hline \multicolumn{11}{|l|}{ Moderator } \\
\hline Environmental turbulence (ET) & & & & & & & $.343^{* * *}$ & $.356^{* * *}$ & $.338^{* * *}$ & $.351^{* * *}$ \\
\hline \multicolumn{11}{|c|}{ Two-way interactions involving human capital } \\
\hline Formal education level x ET & & & & & & & & .003 & & -.001 \\
\hline Management experience $x$ ET & & & & & & & & $.188^{*}$ & & $.179 *$ \\
\hline Industry experience x ET & & & & & & & & $-.122^{\dagger}$ & & $-.132+$ \\
\hline Start-up experience $\times$ ET & & & & & & & & $-.134^{\dagger}$ & & $-.124^{\dagger}$ \\
\hline \multicolumn{11}{|c|}{ Two-way interactions involving social capital } \\
\hline Bonding social capital $\times$ ET & & & & & & & & & -.084 & -.072 \\
\hline Bridging social capital $\times$ ET & & & & & & & & & .017 & .000 \\
\hline F-Change & $5.879 * * *$ & .633 & $2.750^{\dagger}$ & $2.439 *(a)$ & $5.784^{* *}$ & $5.894^{* *(a)}$ & $30.287^{* * *}$ & 1.787 & .906 & $1.399^{(b)}$ \\
\hline Adjusted $\mathrm{R}^{2}$ & 198 & .195 & .212 & .207 & .237 & .248 & .352 & .363 & .351 & .360 \\
\hline
\end{tabular}

Standardized coefficients are shown; $\mathrm{N}=199$; (a) = On top control variables (Model 1); (b) = On top of main effects (Model 6)

***. Significant at the .001 level _ **. Significant at the .01 level — *. Significant at the .05 level -

†. Marginally significant at the .10 level. 
Hypothesis 1 suggested that the business owner's general human capital is positively associated with start-up absorptive capacity, as did hypothesis 2 for specific human capital. Model 2 of Table 2 indicates that the relationship between formal education or management experience and start-up absorptive capacity is insignificant $(\beta=.079 ; \beta=.036 ; \mathrm{p}>.10)$. Hypothesis $1 \mathrm{a}$ and $1 \mathrm{~b}$ are, therefore, not supported. On the other hand, in the case of start-up experience $(\beta=.153)$, we learn from Model 3 of Table 2 that the relationship with absorptive capacity is significant and positive. The owner's industry experience appears to be insignificantly related to start-up absorptive capacity $(\beta=.081 ; p>.10)$. Our findings thus offer support for hypothesis $2 b$ but not for hypothesis $2 \mathrm{a}$.

Hypothesis 3 proposed a negative relationship between the owner's bonding social capital and start-up absorptive capacity. Hypothesis 4 stated that the business owner's bridging social capital is positively associated with start-up absorptive capacity. As shown in Model 5 of Table 2, the relationship of bonding social capital with start-up absorptive capacity appears insignificant $(\beta=-.001 ; p>.10)$. The results, therefore, do not support hypothesis 3 . Conversely, the relationship between bridging social capital and start-up absorptive capacity is positive and significant $(\beta=.220)$. As such, hypothesis 4 is corroborated by our results.

Hypotheses 5 proposed that environmental turbulence acts as a positive moderator of the relationship between the owner's more transferable or flexible capital, such as general human capital and bridging social capital, and start-up absorptive capacity. This relationship is thus expected to be stronger within highly volatile environments compared with more stable environments. Model 8 of Table 2 demonstrates that the cross-product of management experience and environmental turbulence is positive and significant $(\beta=.188)$. Yet, the interaction term with formal education $(\beta=.003$; Model 8), as well as the one with bridging social capital ( $\beta=.017$; Model 9), appear to be insignificant. The positive impact of bridging social capital on absorptive capacity seems unaffected by the environmental conditions under which the start-up operates. Thus, hypothesis 5a (general human capital) only receives partial support, while hypothesis $5 b$ (bridging social capital) receives no support. In addition, the graphical representation of the interaction between management experience and environmental turbulence (Figure 1) depicts that the relationship between management experience and absorptive capacity is indeed positive when environmental turbulence is high. This relationship weakens considerably when environmental turbulence decreases. 
Figure 1 Interaction effect of owner management experience and environmental turbulence on start-up absorptive capacity

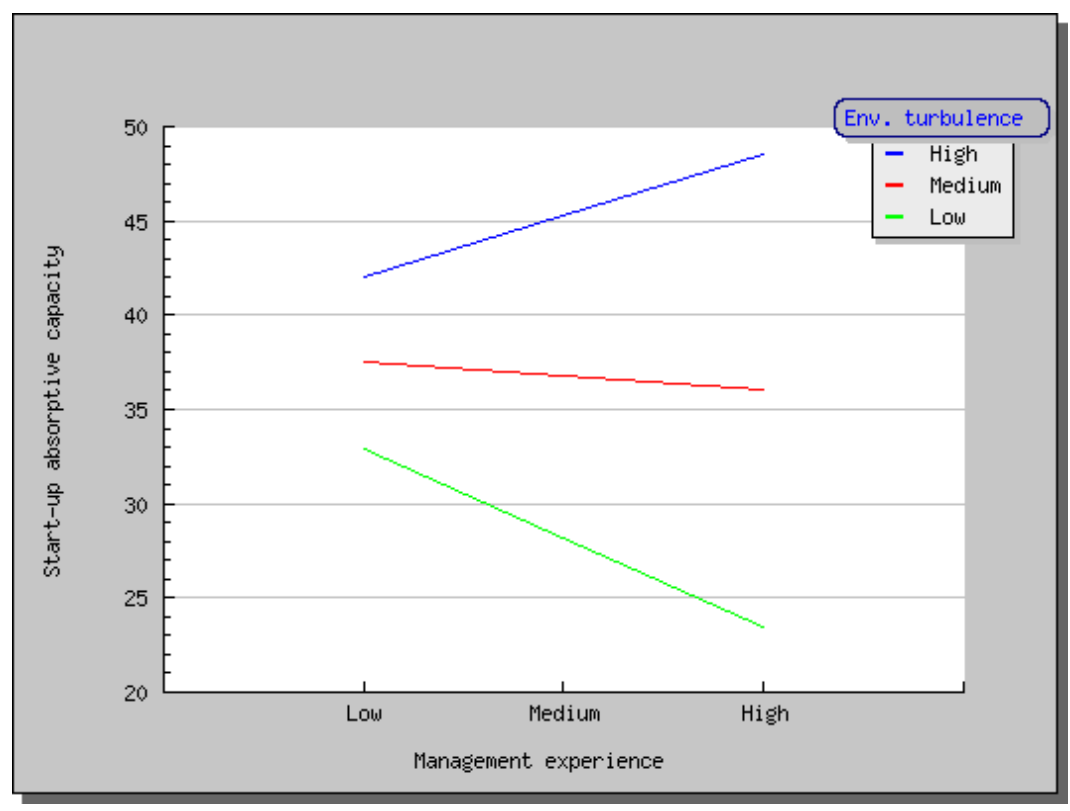

Hypothesis 6 suggested that environmental turbulence is a negative moderator of the relationship between the business owner's less transferable and flexible capital, such as specific human capital and bonding social capital, and start-up absorptive capacity. This relationship is thus expected to be weaker within highly volatile environments compared with more stable environments. With respect to the owner's specific human capital, a significant negative relationship holds for the cross-products involving industry experience $(\beta=-.122)$ and start-up experience $(\beta=-.134)$ (Model 8$)$. The graphical representation of both interactions (Figures 2 and 3) indicates that the relationship of owner specific human capital with start-up absorptive capacity is indeed less positive for start-ups operating in a turbulent environment than for those active within a less turbulent environment. We learn from Model 9 of Table 2 that the cross-product of bonding social capital and environmental turbulence is negative yet insignificant $(\beta=-.084)$. As such, our findings only corroborate hypothesis 6a (specific human capital) and not hypothesis $6 \mathrm{~b}$ (bonding social capital). 
Figure 2 Interaction effect of owner industry experience and environmental turbulence on start-up absorptive capacity

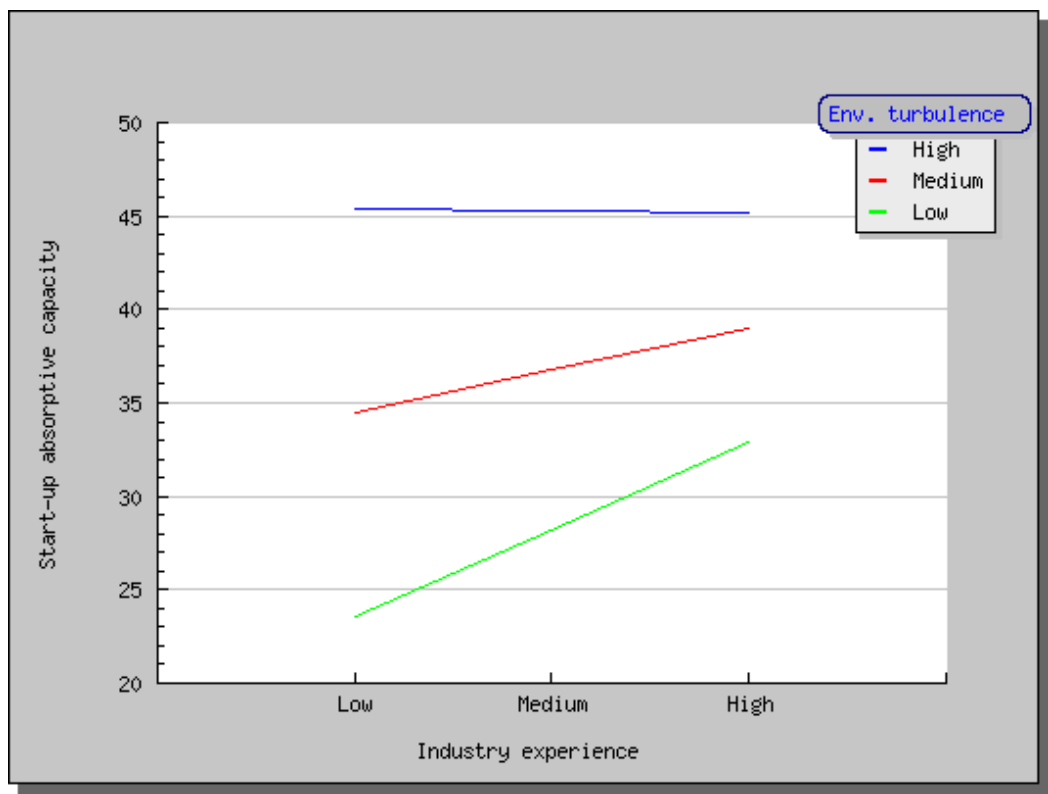

Figure 3 Interaction effect of owner start-up experience and environmental turbulence on start-up absorptive capacity

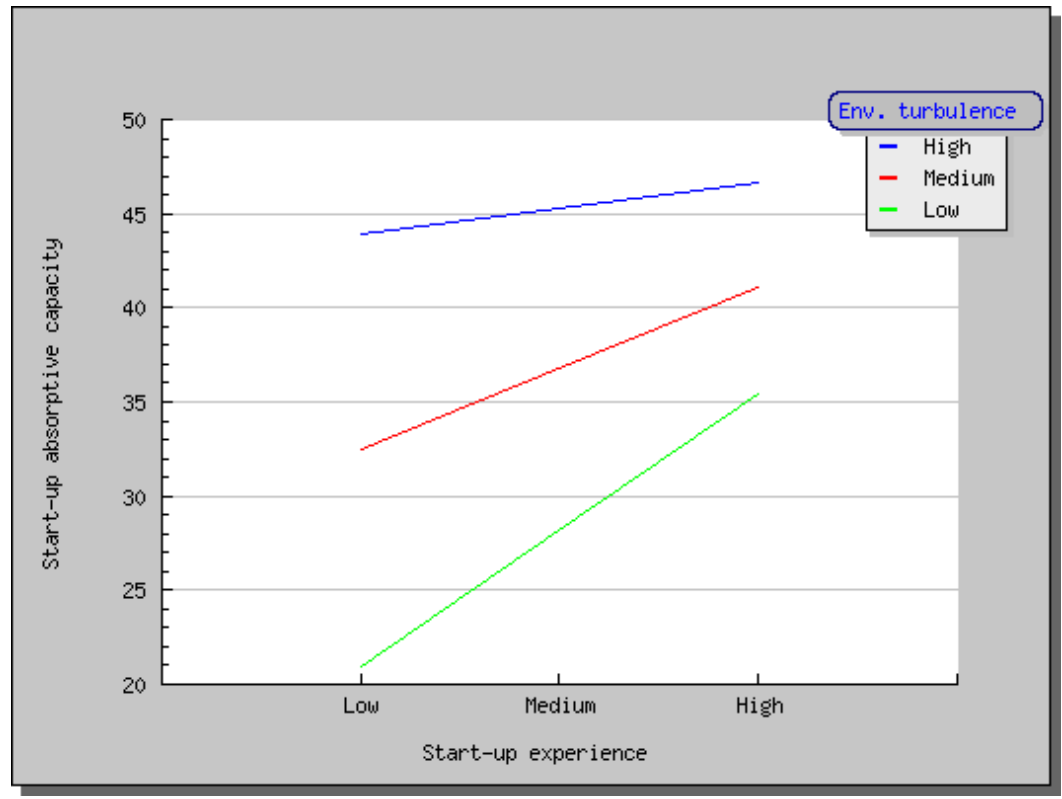


Table 3 provides a summary of this study's hypotheses and results.

Table $3 \quad$ Study hypotheses and results

\begin{tabular}{|c|c|c|}
\hline \multicolumn{2}{|c|}{ Hypothesis } & \multirow{2}{*}{$\begin{array}{c}\text { Finding } \\
\text { Not supported }\end{array}$} \\
\hline $1 \mathrm{a}$ & $\begin{array}{l}\text { The business owner's general human capital is positively associated with } \\
\text { start-up absorptive capacity. This will be reflected in a positive effect of } \\
\text { formal education. }\end{array}$ & \\
\hline $1 b$ & $\begin{array}{l}\text { The business owner's general human capital is positively associated with } \\
\text { start-up absorptive capacity. This will be reflected in a positive effect of } \\
\text { management experience. }\end{array}$ & Not supported \\
\hline $2 \mathrm{a}$ & $\begin{array}{l}\text { The business owner's specific human capital is positively associated with } \\
\text { start-up absorptive capacity. This will be reflected in a positive effect of } \\
\text { industry experience. }\end{array}$ & Not supported \\
\hline $2 b$ & $\begin{array}{l}\text { The business owner's specific human capital is positively associated with } \\
\text { start-up absorptive capacity. This will be reflected in a positive effect of } \\
\text { start-up experience. }\end{array}$ & Supported \\
\hline 3 & $\begin{array}{l}\text { The business owner's bonding social capital is negatively associated } \\
\text { with start-up absorptive capacity. }\end{array}$ & Not supported \\
\hline 4 & $\begin{array}{l}\text { The business owner's bridging social capital is positively associated } \\
\text { with start-up absorptive capacity. }\end{array}$ & Supported \\
\hline $5 a$ & $\begin{array}{l}\text { Environmental turbulence acts as a positive moderator of the relationship } \\
\text { between the business owner's more transferable and flexible capital and } \\
\text { start-up absorptive capacity. This will be reflected in a positive moderation } \\
\text { of the effect of general human capital. }\end{array}$ & Partially supported \\
\hline $5 b$ & $\begin{array}{l}\text { Environmental turbulence acts as a positive moderator of the relationship } \\
\text { between the business owner's more transferable and flexible capital and } \\
\text { start-up absorptive capacity. This will be reflected in a positive moderation } \\
\text { of the effect of bridging social capital. }\end{array}$ & Not supported \\
\hline $6 a$ & $\begin{array}{l}\text { Environmental turbulence acts as a negative moderator of the relationship } \\
\text { between the business owner's less transferable and flexible capital and } \\
\text { start-up absorptive capacity. This will be reflected in a negative moderation } \\
\text { of the effect of specific human capital. }\end{array}$ & Supported \\
\hline $6 b$ & $\begin{array}{l}\text { Environmental turbulence acts as a negative moderator of the relationship } \\
\text { between the business owner's less transferable and flexible capital and } \\
\text { start-up absorptive capacity. This will be reflected in a negative moderation } \\
\text { of the effect of bonding social capital. }\end{array}$ & Not supported \\
\hline
\end{tabular}

\section{DISCUSSION}

The objective of this study was to empirically examine the direct impact of the business owner's human and social capital on the start-up's absorptive capacity. We subsequently tested general and specific human capital, bridging and bonding social capital, and their relationship with environmental turbulence, as antecedents of start-up absorptive capacity. Even though a few empirical contributions to the absorptive capacity literature are set within the context of start-ups, none has yet considered the owner's direct contribution to the construct. Six main hypotheses were developed and tested. We discuss our findings in two sections: general and specific human capital on the one hand and bridging and bonding social capital on the other. 
General and specific human capital. Focusing on the business owner's human capital, we found a significant and positive effect of the owner's start-up experience on absorptive capacity. After introducing environmental turbulence into the model, our results also revealed a significant and positive decreasing impact of owner specific human capital (industry and start-up experience), which was inversely correlated with the turbulence of the startup's environment. The relationship between the owner's management experience and the start-up's absorptive capacity altered from negative within stable environments to positive in volatile environments, as suggested by Figure 1. As far as business owner formal education is concerned, no hypothesized effect on absorptive capacity was corroborated by our results.

A plausible explanation for the effect of formal education is suggested in the resource-based view of the firm (Barney, 1991). According to this approach, a firm is able to build a competitive advantage based on valuable, rare, inimitable and non-substitutable resources. Consequently, for knowledge to constitute a competitive advantage driver, it must comply with these conditions (Autio et al., 2000; Eriksson et al., 1997; Zahra et al., 2000). Formal education mainly assists in the development of explicit knowledge (Davidsson and Honig, 2003), which, by definition, refers to facts and data that can be codified into written documents (Polanyi, 1967). As such, this type of knowledge hardly meets the competitive advantage requirements. Therefore, it could be that the processes underlying organizational absorptive capacity, which may enable the venture to harvest a competitive advantage, profit little from the explicit knowledge accumulated by the owner. Likewise, Thorpe et al. (2005) summarized that what makes knowledge important for start-ups is its experiential origin. Future research could further investigate whether any differences in the owner's direct contribution to start-up absorptive capacity exist according to the type of formal education (e.g. economics versus technical education). Additionally, possible indirect effects of formal education could be explored by investigating its impact on the magnitude and type of experiential knowledge, such as management experience.

The owner's management experience did not have its hypothesized effect of generally increasing start-up absorptive capacity. Instead, the effect of management experience on absorptive capacity is dependent on the degree of perceived turbulence in the start-up's environment. If turbulence is high, then the owner's management experience makes the firm more prone to put in effort to acquire and make use of information from its customer network. If turbulence is low, moderation evidence proposes that more management 
experience decreases start-up absorptive capacity. These findings seem to suggest that there is little point in investigating the relationship between management experience and organizational absorptive capacity without consideration of its interaction with environmental turbulence. The situated relevance of this general human capital measure is in line with the basic premises of social cognitive theory (Bandura, 1986; Hmieleski and Baron, 2009).

Other than the above general human capital effects, our findings also revealed two specific human capital contributions. With respect to start-up experience, our results indicated that prior active participation in the process of starting up new ventures facilitates the owner's direct contribution to start-up absorptive capacity. Our findings also confirmed the existence of a start-up experience decreasing effect on absorptive capacity that is subordinate to environmental turbulence. Reaching back to the work of Shane and Venkataraman (2000) and Ucbasaran et al. (2001) on the activities underlying new venture creation, we find that involvement in start-up emergence and participation in start-up information processing pose comparable challenges to the individual. First, both accommodate for the subjective discovery and recognition of lucrative external knowledge through scanning of the environment. Second, a person's prior accumulated knowledge and cognitive aptitudes assist in evaluating information potential in either process (Lane et al., 2006; Shane and Venkataraman, 2000; Ucbasaran et al., 2001). Finally, both venture emergence and start-up absorptive capacity introduce the individual to resource acquisition and gestation activities that contribute to successful knowledge exploitation. The result of these common characteristics could be that involvement in starting a new venture familiarizes the start-up owner with acquiring, dispersing and interpreting information from the customer network. Hence, the more start-up experience an owner has accumulated, the better his/her preparation for the challenges intrinsic to absorptive capacity. However, we also believe that as external knowledge is subject to aging (Choudhury and Sampler, 1997), so is the owner's preparation for organizational absorptive capacity that stems from prior start-up experience. This aging process is driven by the number of changes in the environment. Because of this, we believe that the usefulness of an owner's preparation for start-up absorptive capacity, and with it, the value of his/her accumulated start-up experience, decreases with environmental turbulence, which is in line with our findings. 
Being the last dimension of (specific) human capital, industry experience also exerted a decreasing significant and positive effect on start-up absorptive capacity. An increase in environmental turbulence corresponded with a decrease in the impact of industry experience on start-up absorptive capacity. More specifically, the part of the owner's direct contribution to absorptive capacity that originates from his/her industry experience declined from being quite strong within stable environments to being virtually non-existent within highly dynamic environments (Figure 2). A probable explanation might be that the effect of industry experience arises from the owner's ability to 'read' the market and understand its specific rules and regulations. That is, knowledge of the industry's dominant players and their preferred strategies, the sector's technology and customer preferences (Gimeno et al., 1997; Shane and Stuart, 2002) may enable the owner to assist the start-up in scanning the environment for notable knowledge, in the interpretation of that knowledge and in distinguishing its finest applications. However, for industry experience to remain valuable to organizational information processing, the owner needs to keep his/her industry-related knowledge up-to-date (Cohen and Levinthal, 1990). In other words, industry experience will only preserve its value if it continues enabling organizations to achieve the goal of acquiring, assimilating and/or exploiting external knowledge (Lane et al., 2006). To establish this in the face of a changing environment, the owner will have to invest in his/her industry knowledge in order to maintain awareness of its players, understand its inherent technology and comprehend customers' preferences. Again, the pace of these investments, as well as the effort and resources they demand, will positively correlate with environmental turbulence (Cohen and Levinthal, 1990; Lichtenthaler, 2009). But, as individual effort and resources are limited, an owner operating in a progressively dynamic environment will find it increasingly difficult to obey to these absorptive capacity (investment) requirements. This might culminate in a point where he/she can no longer keep up, which will cause the business owner's (industry experience-induced) contribution to start-up absorptive capacity to decline. As Figure 2 indicates, this process ultimately leads to a situation in which the owner's direct absorptive capacity contribution from industry experience becomes marginal.

Bridging and bonding social capital. Summarizing our social capital findings, we distinguished a consistent significant and positive main effect of bridging social capital on start-up absorptive capacity. No evidence of any bonding social capital effect emerged. Our results on this matter prove to be consistent with those of earlier research on the entrepreneurial contribution of social capital. For instance, in their longitudinal study on nascent entrepreneurs, Davidsson and Honig (2003) noticed that the importance of bridging social 
capital increased relative to that of bonding social capital during the business developmental process. Fairlie and Robb (2007) concluded that success of business owners, as opposed to self-employment entry, is only weakly correlated with having an entrepreneurial family member. Moreover, while encouragements and aid from a partner, friends, family and acquaintances speed up the pace of founding a business, their impact on firm functioning and business results has been found to be less clear (Baucus and Human, 1994; Jennings and McDougald, 2007; Moore and Mueller, 2002). This study sheds some additional light on this issue by demonstrating that (even) in the context of start-up absorptive capacity, the owner's bonding social capital appears to exert no significant influence, irrespective of the environmental conditions under which the start-up operates.

As to the mechanisms that govern this social capital outcome, our findings seem to suggest that start-up absorptive capacity requires the deployment of a kind of specialized knowing-who, which is less common than the assistance offered by a business owner's strong ties. We know that during the venture's gestation phase, bonding social capital is highly important both in terms of resources and support (Davidsson and Honig, 2003). It generates the firm's initial network structure, which in turn influences the development of broader networks of weak ties (Arrègle et al., 2007). Bridging social capital is, therefore, more 'developed' or venture-tailored (firm specific) than bonding social capital. Its relatedness with the firm's activities and environment is likely to be stronger, which in turn facilitates its knowledge processing role. Additionally, while we recognize that organizational absorptive capacity is not only a function of the gatekeeper's expertise (Cohen and Levinthal, 1990), with 'gatekeeper' being a role often embodied by the start-up business owner, we do believe that it is mainly his/her network of weak ties that acts as an interface between the firm and its environment. Specifically, the owner is (commonly) the face of the company and the person people turn to when they want to interact with the business on important matters. As a result, the owner's weak ties constitute an excellent means to gather external information and introduce it into the start-up, to gain the resources needed for the assimilation of external information, and to point out where the market knowledge application might be most profitable. In all, although aid from a partner, friends, family and other strong ties is found to be positively associated with the probability of entering self-employment (Dunn and HoltzEakin, 2000; Fairlie and Robb, 2007; Lentz and Laband, 1990), it appears not to provide the assistance or access to resources required for organizational absorptive capacity, which is a task well-covered by the business owner's network of loose relationships. 
The above findings should not be interpreted without some caveats in mind. First, our data could be biased with social desirability since the company questionnaire may have been completed by the interview respondent, being the start-up business owner. However, the threat of common-method variance was weakened through the use of a bipartite approach (questionnaire and interview) together with mixed types of questions and measures (both factual and verifiable behaviors and events) (Chandler and Lyon, 2009; Podsakoff et al., 2003). Second, it is difficult to judge causality from a cross-sectional research design. Therefore, in order to validate the posited relationships, a longitudinal research design should be set up to replicate our findings. Finally, within our sample, environmental turbulence was identified based on the perception of the business owner. Actual environmental dynamism and uncertainty may deviate from this subjective perception. To address this, future research could include additional, more stringent environmental criteria such as market entry, market exit and number of patents.

Through our model and findings reported in this article, we identify several opportunities for future research. First, individual abilities that contribute to a firm's organizational absorptive capacity need to be further uncovered and investigated. Examples of additional indicators of human and social capital are the nature of the education, attendance at business classes, the number of organizations worked for and motivational factors (Davidsson and Honig, 2003). Second, previous research has suggested that human and social capital build upon each other (Coleman, 1990; Davidsson and Honig, 2003; Nahapiet and Ghoshal, 1998). Weak ties, in particular, have been identified as critical gateways for the exchange of otherwise scarce information, and the assimilation of this information adds to the accumulation of insights and experience (human capital). The reverse might also be true: human capital might amplify social capital. For instance, knowing the rules of the game could assist in building up a network of contacts, and likewise, start-up and industry experience may be beneficial in addressing suppliers and customers. Therefore, further research should investigate how human and social capital interact in their relationship with absorptive capacity. Third, apart from our research emphasis on the owner's direct contribution, we expect his/her human and social capital to also indirectly affect absorptive capacity through the implementation and gestation of managerial practices (e.g. definition of organizational tasks and allocation of resources). We encourage scholars to look into the probable indirect absorptive capacity influence of the owner's human and social capital. Fourth, a new venture's capacity to acquire, assimilate and exploit external information does not only depend on the 
direct or indirect contribution of the owner. Though often ignored in absorptive capacity literature, employees constitute a very important pillar of the firm's knowledge base (Muscio, 2007). As such, exploring employee human and social capital, and management practices directed at developing and maintaining it, may equally advance our understanding of absorptive capacity. Future research should also address the topic of knowledge complementarity within a firm's knowledge base. According to Cohen and Levinthal (1990), an inter-individual confrontation of knowledge triggers synergetic effects and induces new insights that permit the interpretation of previously incomprehensible information. So, a diversity of knowledge structures within an entrepreneurial team or within the venture may allow the start-up to tap into previously incomprehensible knowledge sources. 


\section{REFERENCES}

Adler, P.S., \& Kwon, S.W. (2002). Social capital: Prospects for a new concept. Academy of Management Review, 27(1), 17-40.

Ahuja, G., \& Lampert, C.M. (2001). Entrepreneurship in the large corporation: A longitudinal study of how established firms create breakthrough inventions. Strategic Management Journal, 22(6/7), 521-543.

Anderson, J.C., \& Gerbing, D.W. (1988). Structural equation modeling in practice: A review and recommended two-step approach. Psychological Bulletin, 103(3), 411-423.

Arrègle, J.L., Hitt, M.A., Sirmon, D.G., \& Very, P. (2007). The development of organizational social capital: Attributes of family firms. Journal of Management Studies, 44(1), 73-95.

Autio, E., Sapienza, H.J., \& Almeida, J.G. (2000). Effects of age at entry, knowledge intensity, and imitability on international growth. Academy of Management Journal, 43(5), 909-924.

Bandura, A. (1986). Social foundations of thought and action: A social cognitive theory. Englewood Cliffs, NJ: Prentice Hall.

Barney, J. (1991). Firm resources and sustained competitive advantage. Journal of Management, 17(1), 99-120.

Barringer, B.R., \& Bluedorn, A.C. (1999). The relationship between corporate entrepreneurship and strategic management. Strategic Management Journal, 20(5), 421-444.

Bates, T. (1990). Entrepreneur human capital inputs and small business longevity. Review of Economics and Statistics, 72(4), 551-559.

Baucus, D.A., \& Human, S.E. (1994). Second-career entrepreneurs: A multiple case study analysis of entrepreneurial processes and antecedent variables. Entrepreneurship: Theory \& Practice, 19(2), 41-71.

Becherer, R.C., \& Maurer, J.G. (1997). The moderating effect of environmental variables on the entrepreneurial and marketing orientation of entrepreneur-led firms. Entrepreneurship: Theory \& Practice, 22(1), 47-58.

Becker, G.S. (1993). Nobel lecture: The economic way of looking at behaviour. Journal of Political Economy, 101(3), 385-409.

Bierly, P.E.III, Damanpour, F., \& Santoro, M.D. (2009). The application of external knowledge: Organizational conditions for exploration and exploitation. Journal of Management Studies, 46(3), 481-509.

Boeker, W. (1997). Executive migration and strategic change: The effect of top manager movement on product market entry. Administrative Science Quarterly, 42(2), 213-236. 
Bosma, N., van Praag, M., Thurik, R., \& de Wit, G. (2004). The value of human and social capital investments for the business performance of start-ups. Small Business Economics, 23(3), 227-236.

Browne, M.W., \& Cudeck, R. (1993). Alternative ways of assessing model fit. In K.A. Bollen, \& J.S. Long (Eds.), Testing structural equation models (pp. 136-162). Beverly Hills, CA: Sage Publications.

Brush, C.G., Greene, P.G., \& Hart, M.M. (2001). From initial idea to unique advantage: The entrepreneurial challenge of constructing a resource base. Academy of Management Executive, 15(1), 64-78.

Chandler, G.N., \& Lyon, D.W. (2009). Involvement in knowledge-acquisition activities by venture team members and venture performance. Entrepreneurship: Theory $\mathcal{E}$ Practice, 33(3), 571-592.

Choudhury, V., \& Sampler, J.L. (1997). Information specificity and environmental scanning: An economic perspective. Management Information Systems Quarterly, 21(1), 25-53.

Cohen, W.M., \& Levinthal, D.A. (1990). Absorptive capacity: A new perspective on learning and innovation. Administrative Science Quarterly, 35(1), 128-152.

Coleman, J.S. (1990). Foundations of social theory. Cambridge, MA: Harvard University Press.

Davidsson, P., \& Honig, B. (2003). The role of social and human capital among nascent entrepreneurs. Journal of Business Venturing, 18(3), 301-331.

De Carolis, D.M., Litzky, B.E., \& Eddleston, K.A. (2009). Why networks enhance the progress of new venture creation: The influence of social capital and cognition. Entrepreneurship: Theory \& Practice, 33(2), 527-545.

De Clercq, D., Sapienza, H.J., \& Crijns, H. (2005). The internationalization of small and medium-sized firms. Small Business Economics, 24(4), 409-419.

Dimov, D. (2010). Nascent entrepreneurs and venture emergence: Opportunity confidence, human capital, and early planning. Journal of Management Studies, 47(6), 1123-1153.

Dunn, T., \& Holtz-Eakin, D. (2000). Financial capital, human capital, and the transition to self-employment: Evidence from intergenerational links. Journal of Labor Economics, 18(2), 282-305.

Eisenhardt, K.M., \& Martin, J.A. (2000). Dynamic capabilities: What are they? Strategic Management Journal, 21(10/11), 1105-1121.

Eriksson, K., Johanson, J., Majkard, A., \& Sharma, D. (1997). Experiential knowledge and cost in the internationalization process. Journal of International Business Studies, 28(2), 337-360.

Fairlie, R.W., \& Robb, A. (2007). Families, human capital, and small business: Evidence from the characteristics of business owners survey. Industrial and Labor Relations Review, 60(2), 225-245. 
Fiet, J.O. (1996). The informational basis of entrepreneurial discovery. Small Business Economics, 8(6), 419-430.

Gimeno, J., Folta, T.B., Cooper, A.C., \& Woo, C.Y. (1997). Survival of the fittest? Entrepreneurial human capital and the persistence of underperforming firms. Administrative Science Quarterly, 42(4), 750-783.

Granovetter, M.S. (1983). The strength of weak ties: A network theory revisited. Sociological Theory, 1, 201-233.

Hair, J.F., Anderson, R.E., Tatham, R.L., \& Black, W.C. (1998). Multivariate data analysis (5th edn.). Upper Saddle River, NJ: Prentice Hall.

Hansen, M.T. (1999). The search-transfer problem: The role of weak ties in sharing knowledge across organizational subunits. Administrative Science Quarterly, 44(1), 82-111.

Hatch, N., \& Dyer, J. (2004). Human capital and learning as a source of sustainable competitive advantage. Strategic Management Journal, 25(12), 1155-1178.

Hayton, J. (2005). Promoting corporate entrepreneurship through human resource management practices: A review of empirical research. Human Resource Management Review, 15(1), 21-41.

Hmieleski, K.M., \& Baron, R.A. (2009). Entrepreneurs' optimism and new venture performance: A social cognitive perspective. Academy of Management Journal, 52(3), 473-488.

Ireland, R.D., Hitt, M.A., \& Vaidyanath, D. (2002). Alliance management as a source of competitive advantage. Journal of Management, 28(3), 413-446.

Jansen, J.J.P., Van den Bosch, F.A.J., \& Volberda, H.W. (2005). Managing potential and realized absorptive capacity: How do organizational antecedents matter? Academy of Management Journal, 48(6), 999-1015.

Jansen, J.J.P., Van den Bosch, F.A.J., \& Volberda, H.W. (2006). Exploratory innovation, exploitative innovation, and performance: Effects of organizational antecedents and environmental moderators. Management Science, 52(11), 1661-1674.

Jennings, J.E., \& McDougald, M.S. (2007). Work-family interface experiences and coping strategies: Implications for entrepreneurship research and practice. Academy of Management Review, 32(3), 747-760.

Kang, S.C., Morris, S.S., \& Snell, S.A. (2007). Relational archetypes, organizational learning, and value creation: Extending the human resource architecture. Academy of Management Review, 32(1), 236-256.

Keh, H.T., Nguyen, T.T.M., \& Ng, H.P. (2007). The effects of entrepreneurial orientation and marketing information on the performance of SMEs. Journal of Business Venturing, 22(4), 592-611. 
Kleinbaum, D.G., Kupper, L.L., Muller, K.E., \& Nizam, A. (1998). Applied regression analysis and other multivariable methods (3rd edn.). Pacific Grove, CA: Duxbury Press.

Kohli, A.K., Jaworski, B.J., \& Kumar, A. (1993). Markor: A measure of market orientation. Journal of Marketing Research, 30(4), 467-477.

Lane, P.J., Koka, B.R., \& Pathak, S. (2006). The reification of absorptive capacity: A critical review and rejuvenation of the construct. Academy of Management Review, 31(4), 833-863.

Leana, C.R., \& Van Buren, H.J.III. (1999). Organizational social capital and employment practices. Academy of Management Review, 24(3), 538-555.

Lentz, B., \& Laband, D. (1990). Entrepreneurial success and occupational inheritance among proprietors. Canadian Journal of Economics, 23(3), 563579.

Levinthal, D.A., \& March, J.G. (1993). The myopia of learning. Strategic Management Journal, 14(2), 95-112.

Liao, J., Welsch, H., \& Stoica, M. (2003). Organizational absorptive capacity and responsiveness: An empirical investigation of growth-oriented SMEs. Entrepreneurship: Theory E Practice, 28(1), 63-85.

Lichtenthaler, U. (2009). Absorptive capacity, environmental turbulence, and the complementarity of organizational learning processes. Academy of Management Journal, 52(4), 822-846.

Lin, N., Ensel, W.M., \& Vaughn, J.C. (1981). Social resources and strength of ties: Structural factors in occupational status attainment. American Sociological Review, 46 (4), 393-405.

Maes, J. \& Sels, L. (forthcoming). SMEs' radical product innovation: The role of internally and externally oriented knowledge capabilities. Journal of Small Business Management.

Maes, J., Sels, L., \& Roodhooft, F. (2005). Modeling the link between management practices and financial performance. Evidence from small construction companies. Small Business Economics, 25(1), 17-34.

Miller, D., \& Friesen, P.H. (1983). Strategic making and environment: The third link. Strategic Management Journal, 4(3), 221-235.

Moore, C.S., \& Mueller, R.E. (2002). The transition from paid to selfemployment in Canada: The importance of push factors. Applied Economics, 34(6), 791-801.

Moreno, A.M., \& Casillas, J.C. (2008). Entrepreneurial orientation and SMEs: A causal model. Entrepreneurship: Theory \& Practice, 32(3), 507-528.

Mowery, D.G., Oxley, J.E., \& Silverman, B.S. (1996). Strategic alliances and interfirm knowledge transfer. Strategic Management Journal, 17, 77-91.

Muscio, A. (2007). The impact of absorptive capacity on SMEs' collaboration. Economics of Innovation $\mathcal{E}$ New Technology, 16(8), 653-668. 
Nahapiet, J., \& Ghoshal, S. (1998). Social capital, intellectual capital, and the organizational advantage. Academy of Management Review, 23(2), 242-266.

Nicholls-Nixon, C., Cooper, A.C., \& Woo, C.Y. (2000). Strategic experimentation: Understanding change and performance in new ventures. Journal of Business Venturing, 15(5), 493-521.

Ocasio, W. (1997). Towards an attention-based view of the firm. Strategic Management Journal, 18(1), 187-206.

Podsakoff, P.M., MacKenzie, S.B., Lee, J.Y., \& Podsakoff, N.P. (2003). Common method biases in behavioral research: A critical review of the literature and recommended remedies. Journal of Applied Psychology, 88(5), 879-903.

Polanyi, M. (1967). The tacit dimension. London: Routledge and Kegan Paul.

Portes, A. (1998). Social capital: Its origins and applications in modern sociology. Annual Review of Sociology, 24(1), 1-24.

Sapienza, H.J., Autio, E., George, G., \& Zahra, S.A. (2006). A capabilities perspective on the effects of early internationalization on firm survival and growth. Academy of Management Review, 31(4), 914-933.

Sapienza, H.J., De Clercq, D., \& Sandberg, W.R. (2005). Antecedents of international and domestic learning effort. Journal of Business Venturing, 20(4), 437-457.

Shane, S., \& Stuart, T. (2002). Organizational endowments and the performance of university start-ups. Management Science, 48(1), 154-170.

Shane, S., \& Venkataraman, S. (2000). The promise of entrepreneurship as a field of research. Academy of Management Review, 25(1), 217-226.

Simon, L., \& Davies, G. (1996). A contextual approach to management learning. Organization Studies, 17(2), 269-289.

Smeltzer, L.R., Fann, G.L., \& Nikolaisen, V.N. (1988). Environmental scanning practices in small business. Journal of Small Business Management, 26(3), 55 62.

Smith, K.G., Collins, C.J., \& Clark, K.D. (2005). Existing knowledge, knowledge creation capability, and the rate of new product introduction in high-technology firms. Academy of Management Journal, 48(2), 346-357.

Thorpe, R., Holt, R., Macpherson, A., \& Pittaway, L. (2005). Using knowledge within small and medium-sized firms: A systematic review of the evidence. International Journal of Management Reviews, 7(4), 257-281.

Todorova, G., \& Durisin, B. (2007). Absorptive capacity: Valuing a reconceptualization. Academy of Management Review, 32(3), 774-786.

Tsai, W.P. (2001). Knowledge transfer in intra-organizational networks: Effects of network position and absorptive capacity on business unit innovation and performance. Academy of Management Journal, 44(5), 9961004. 
Ucbasaran, D., Westhead, P., \& Wright, M. (2001). The focus of entrepreneurial research: Contextual and process issues. Entrepreneurship: Theory \& Practice, 25(4), 57-80.

Ucbasaran, D., Westhead, P., \& Wright, M. (2008). Opportunity identification and pursuit: Does an entrepreneur's human capital matter? Small Business Economics, 30(2), 153-173.

Verhees, F.J.H.M., \& Meulenberg, M.T.G. (2004). Market orientation, innovativeness, product innovation and performance in small firms. Journal of Small Business Management, 42(2), 134-154.

West, G.P.III, \& Noel, T.W. (2009). The impact of knowledge resources on new venture performance. Journal of Small Business Management, 47(1), 1-22.

Wiklund, J., \& Shepherd, D.A. (2003). Knowledge-based resources, entrepreneurial orientation, and the performance of small and mediumsized businesses. Strategic Management Journal, 24(13), 1307-1314.

Yli-Renko, H., Autio, E., \& Sapienza, H.J. (2001). Social capital, knowledge acquisition, and knowledge exploitation in young technology-based firms. Strategic Management Journal, 22(6/7), 587-613.

Zahra, S.A. (1993). Environment, corporate entrepreneurship, and financial performance: A taxonomic approach. Journal of Business Venturing, 8(4), 319-340.

Zahra, S.A., \& Filatotchev, I. (2004). Governance of the entrepreneurial threshold firm: A knowledge-based perspective. Journal of Management Studies, 41(5), 885-897.

Zahra, S.A., \& George, G. (2002). Absorptive capacity: A review, reconceptualization and extension. Academy of Management Review, 27(2), 185-203.

Zahra, S.A., Ireland, R.D., \& Hitt, M.A. (2000). International expansion by new venture firms: International diversity, model of market entry, technological learning, and performance. Academy of Management Journal, 43(5), 925-950.

Zhang, M., Macpherson, A., \& Jones, O. (2006). Conceptualizing the learning process in SMEs. International Small Business Journal, 24(3), 299-323. 


\section{APPENDIX}

\section{Appendix A Factor loadings and Cronbach's alphas}

\begin{tabular}{|c|c|c|}
\hline & Environmental turbulence & Absorptive capacity \\
\hline Our industry offers a lot of interesting possibilities for future growth. & .691 & .190 \\
\hline Within our industry a lot of opportunities for new products and/or new services exist. & .855 & .265 \\
\hline Within our industry customer demand for new products and/or new services is increasing. & .854 & .263 \\
\hline Within our industry the need for a new technology is growing. & .730 & .402 \\
\hline Within our industry the market for new products and/or new services is expanding. & .858 & .294 \\
\hline Within our industry possibilities for venture growth are numerous. & .792 & .366 \\
\hline Within our industry continuous business investments in R\&D are required in order not to fall behind. & .698 & .449 \\
\hline We have business meetings at least once every quarter to discuss market trends and developments. & .275 & .763 \\
\hline In this business, we meet with customers at least once a year to find out what products or services they will need in the future. & .216 & .724 \\
\hline In this business, we do a lot of in-house market research. & .396 & .801 \\
\hline We periodically review our product development efforts to ensure that they are in line with what customers want. & .383 & .812 \\
\hline We get together periodically to plan a response to changes taking place in our business environment. & .240 & .809 \\
\hline $\mathbf{N}$ & 199 & 199 \\
\hline Cronbach's alpha & .894 & .841 \\
\hline
\end{tabular}

Extraction Method: Principal Components Analysis; Promax rotation; To compute both factors we made use of the following formula to obtain one single score: $F=((S-V) /((V \cdot W)-V)) \times 100$ with $S$ equal to the sum of all initial values (before transformation), $V$ referring to the number of variables and $W$ representing the number of scale points (Maes et al., 2005). 